\title{
UJI AKTIVITAS PENGHAMBATAN POLIMERISASI HEME (1)-N-(2-NITROBENZIL)-1,10- FENANTROLINIUM IODIDA DAN (1)-N-(4-NITROBENZIL)-1,10- FENANTROLINIUM IODIDA SECARA IN VITRO
}

\author{
IN VITRO ANALYSIS OF THE HEME POLYMERIZATION \\ INHIBITORY ACTIVITY FROM (1)-N-(2-NITROBENZYL)-1,10- \\ PHENANTROLINIUM IODIDE AND (1)-N-(4-NITROBENZYL)- \\ 1,10-PHENANTROLINIUM IODIDE
}

\author{
Laela Hayu Nurani ${ }^{1}$, Dwi Utami ${ }^{1}$, Wahyu Widyaningsih ${ }^{1}$, Iin Narwanti ${ }^{1}$, Eti \\ Nurwening ${ }^{2}$, Jumina ${ }^{3}$ \\ ${ }^{1}$ Fakultas Farmasi Universitas Ahmad Dahlan Yogyakarta \\ Jl Prof. Dr. Soepomo, Janturan Yogyakarta \\ ${ }^{2}$ Fakultas Kedokteran, Universitas Gadjah Mada, Sekip Utara Yogyakarta \\ ${ }^{3}$ Fakultas MIPA, Universitas Gadjah Mada, Sekip Utara Yogyakarta \\ Email: laelafarmasi@yahoo.com
}

\begin{abstract}
ABSTRAK
Kemampuan penghambatan polimerisasi heme (1)-N-(2-nitrobenzil)-1,10-fenantrolinium iodida dan (1)-N-(4-nitrobenzil)-1,10-fenantrolinium iodida telah diteliti. Tujuan dilakukan penelitian ini adalah untuk mengetahui kemampuan dari senyawa baru (1)-N-(2-nitrobenzil)1,10-fenantrolinium iodida dan (1)-N-(4-nitrobenzil)-1,10-fenantrolinium iodida dalam menghambat polimerisasi heme. Penelitian ini menggunakan metode eksperimental secara in vitro. Aktivitas penghambatan polimerisasi heme dilihat berdasarkan nilai $\mathrm{IC}_{50}$ (konsentrasi ekstrak yang mampu menghambat polimerisasi heme hingga 50\%). Nilai IC $_{50}$ diperoleh menggunakan analisis probit. Aktivitas penghambatan polimerisasi heme ditunjukkan dengan nilai IC $_{50}$ Nilai IC $_{50}$ senyawa (1)-N-(2-nitrobenzil)-1,10-fenantrolinium iodida tidak dapat ditentukan. Nilai IC $_{50}$ senyawa (1)-N-(4-nitrobenzil)-1,10-fenantrolinium iodida dan klorokuin secara berturut-turut adalah $0,571 \pm 0,071 ; 25,498 \pm 1,876 \mathrm{mg} / \mathrm{mL}$. Hasil penelitian menunjukkan bahwa senyawa (1)-N-(4-nitrobenzil)-1,10-fenantrolinium iodida memiliki kemampuan penghambatan polimerisasi heme yang lebih baik jika dibandingkan dengan klorokuin sedangkan senyawa (1)-N-(2-nitrobenzil)-1,10-fenantrolinium iodida tidak memiliki aktivitas penghambatan polimerisasi heme.
\end{abstract}

Kata kunci: Polimerisasi heme, (1)-N-(2-nitrobenzil)-1,10- fenantrolinium iodida, (1)-N-(4nitrobenzil)-1,10- fenantrolinium iodida, klorokuin, malaria

\section{ABSTRACT}

The inhibitory activity of heme polymerization of (1)-N-(2-nitrobenzyl)-1,10phenantrolinium iodide and (1)-N-(4-nitrobenzyl)-1,10-phenantrolinium iodide have been done. This study aims to analyse the (1)-N-(2-nitrobenzyl)-1,10-phenantrolinium iodide and (1)-N-(4-nitrobenzyl)-1,10-phenantrolinium iodide as inhibitory of polimerization heme. Analysis of heme inhibtory polimerization activity used the experimental in vitro method. The activity showed by $\mathrm{IC}_{50}$ (the capable concentration of extract to inhibiting polymerization heme 
by $50 \%$ ). The $\mathrm{IC}_{50}$ value acquired by probit analysis. Assess $\mathrm{IC}_{50}$ of (1)-N-(2-nitrobenzyl)1,10-phenantrolinium iodide not to be identified, (1)-N-(4-nitrobenzyl)-1,10-phenantrolinium iodide and chloroquine by successively are $0,571 \pm 0,071 ; 25,498 \pm 1,876 \mathrm{mg} / \mathrm{mL}$. The result showed the (1)-N-(4-nitrobenzyl)-1,10-phenantrolinium iodide had the highest value of the heme polymerization inhibitory activity than chloroquin, (1)-N-(2-nitrobenzyl)-1,10phenantrolinium iodide hadn't the heme polymerization inhibitory activity.

Key words: Polymerization heme, (1)-N-(2-nitrobenzyl)-1,10-phenantrolinium iodide, (1)-N(4-nitrobenzyl)-1,10-phenantrolinium iodide, choloroquin, malaria

\section{PENDAHULUAN}

Resistensi obat malaria adalah kemampuan dari parasit untuk terus hidup dalam tubuh manusia, berkembang biak dan menimbulkan gejala penyakit meskipun telah diberikan pengobatan secara teratur baik dengan dosis standart maupun dengan dosis yang lebih tinggi yang masih bisa ditolerir oleh pemakai obat. Resistensi parasit Plasmodium falciparum terhadap obat-obatan merupakan masalah di daerah endemik. Di wilayah-wilayah endemik, peningkatan resistensi parasit terhadap obat-obatan yang ada merupakan salah satu penyebab tingginya angka morbiditas dan mortalitas akibat malaria (Kublin et al., 2003).

Salah satu obat antimalaria yang sering digunakan dalam pengobatan malaria yaitu klorokuin. Efektifitas klorokuin terbatas pada saat parasit malaria berada dalam tahap eritrositik. Beberapa fakta menunjukkan bahwa klorokuin bekerja di dalam vakuola makanan dari parasit. Klorokuin bekerja dengan mengikat cincin feriprotoporfirin IX suatu hematin yang merupakan hasil metabolisme hemoglobin didalam parasit. Ikatan feriprotofirin IX dari klorokuin ini bersifat melisiskan membran parasit sehingga mati. Konsentrasi sitotoksik dari klorokuin pada vakuola dapat menghambat pembentukan hemozoin pada eritrosit (Kublin et al., 2003).

Saat ini level resistensi parasit terhadap klorokuin semakin tinggi, walaupun demikian sampai sekarang klorokuin masih digunakan di beberapa tempat di dunia (Winstanley et al., 2004). Pada umumnya bila resistensi terhadap suatu obat antimalaria sudah terjadi akan diikuti dengan resistensi terhadap obat antimalaria lainnya. Tekanan obat yang terus menerus menyebabkan parasit akan memasuki jalur metabolisme yang lain dan menyebabkan terjadinya mutasi. Dengan demikian parasit terhindar dari pengaruh obat. Hal inilah yang menyebabkan resistensi parasit terhadap obat antimalaria terjadi secara perlahan-lahan (Cowman et al., 1994).

Usaha untuk mengatasi resistensi klorokuin adalah menemukan antimalaria baru yang memiliki mekanisme aksi yang sama dan efek samping minimal. Telah dilakukan uji antiplasmodium pada derivat 1, 10 fenantrolin dibandingkan dengan klorokuin, ternyata derivat fenantrolin memiliki aktivitas yang lebih baik dengan $\mathrm{IC}_{50} 0,3 \mu \mathrm{M}$ (Yapi et al., 2000), dan Mustofa et al., 2003 telah mensintesis 13 derivat 1,10 fenantrolin dan dievaluasi kemampuan antiplasmodium secara in vitro dan hasilnya menunjukkan bahwa senyawa (1)- $N$-alkil- dan (1)- $N$-benzil-1,10fenantrolinium,(1)- $N$-metil-1,10-

fenantrolinium sulfat, (1)- $N$-etil-1,10fenantrolinium sulfat, (1)- $N$-benzil-1,10fenantrolinium klorida, (1)- $N$-benzil-1,10fenanthrolinium bromida dan (1)- $N$-benzil1,10-fenantrolinium iodida memiliki kemampuan sebagai antiplasmodium.

Berdasarkan analisis terhadap senyawa turunan (1)-N-benzil-1,10-fenantrolium iodida yang telah ada tersebut, perlu dilakukan modifikasi struktur terhadap senyawa (1)-Nbenzil-1,10-fenantrolium iodida untuk meningkatkan stabilitas dan aktivitas 
antiplasmodialnya. Dalam penelitian ini diusulkan pengembangan senyawa baru turunan (1)-N-benzil-1,10-fenantrolin dengan substituent gugus nitro $\left(\mathrm{NO}_{2}\right)$ pada gugus benzil. Gugus nitro merupakan suatu gugus dengan stabil terhadap hidrolisis ataupun oksidasi (Mc Murryet al., 2004). Sesuai dengan HKSA dari senyawa pada benzil penurunan muatan bersih pada atom N1 akan meningkatkan aktivitas antimalaria (Mustofa et al, 2002), maka diharapkan senyawa baru ini memiliki aktivitas antimalaria yang lebih tinggi. Dengan demikian perlu dilakukan kajian aktivitas antimalaria dari turunan (1)- $\mathrm{N}$ (benzil)-1,10-fenantrolium iodida dengan substituen termodifikasi gugus electron withdrawing groups (Nitro). Untuk membuktikan dugaan tersebut perlu ditentukan mekanisme kerja antimalaria melalui penghambatan polimerisasi heme secara in vitro menggunakan metode Basillico yang dimodifikasi.

\section{METODE PENELITIAN}

Alat

Neraca analitik (BP 221 S), sentrifugator (Universal $32 \mathrm{R}$ ), inkubator (Lab Line), ELISA reader (Bio-Rad Benchmark), effendorf, mikrokultur 96 sumuran steril (Nalgene Nunc International, Denmark).

\section{Bahan}

Bahan yang digunakan adalah (1)-N-(2nitrobenzil)-1,10- fenantrolinium iodida, (1)$\mathrm{N}$-(4-nitrobenzil)-1,10- fenantrolinium iodida, $\mathrm{NaOH}(0,2 \mathrm{M}, 0,1 \mathrm{M})$, aquades, hematin, DMSO (100\% dan 10\%), asam asetat glasial, klorokuin, etanol 96\%.

\section{Jalan Penelitian}

Uji penghambatan polimerisasi heme dilakukan menggunakan metode Basillico yang dimodifikasi. Sebanyak $100 \mu \mathrm{L}$ larutan hematin $1 \mathrm{mM}$ dalam $\mathrm{NaOH} \quad 0,2 \quad \mathrm{M}$ dimasukkan ke dalam tabung effendorf, kemudian ditambahkan $50 \mu \mathrm{L}$ bahan uji dengan berbagai tingkatan kadar, yaitu 5,00; 2,50; 1,25; 0,63; dan 0,31 mg/mL. Replikasi sebanyak 3 kali untuk masing-masing kadar. Untuk memudahkan pembuatan larutan ekstrak dan klorokuin, proses pelarutannya ditambahkan DMSO hingga konsentrasi DMSO 10\% (Guetzoyan et al., 2009).

Untuk memulai reaksi polimerisasi heme, tambahkan $50 \mu \mathrm{L}$ larutan asam asetat glasial $(\mathrm{pH} 2,6)$ pada tabung effendorf yang sudah berisi larutan hematin dan sampel, kemudian inkubasi pada suhu $37{ }^{\circ} \mathrm{C}$ selama 24 jam. Sebagai kontrol positif adalah klorokuin difosfat, sedangkan sebagai kontrol negatif adalah akuades dan larutan DMSO $10 \%$.

Setelah inkubasi berakhir, tabung effendorf disentrifuse dengan kecepatan 8000 rpm selama 10 menit. Buang supernatannya, endapan dicuci sebanyak 4 kali dengan 200 $\mu \mathrm{L}$ DMSO. Masing-masing pencucian dengan cara disentrifuse berkecepatan $8000 \mathrm{rpm}$ selama 10 menit. Endapan yang diperoleh ditambah $200 \mu \mathrm{L} \mathrm{NaOH} \mathrm{0,1} \mathrm{M.} \mathrm{Setiap} 100 \mu \mathrm{L}$ larutan yang diperoleh dimasukkan ke dalam mikroplate 96 sumuran dan dibaca nilai OD dengan Elisa reader pada panjang gelombang $405 \mathrm{~nm}$.

Nilai aktivitas penghambatan polimerisasi heme dinyatakan dalam IC $_{50}$ yaitu kadar yang mampu menghambat polimerisasi heme hingga $50 \%$ yang dibandingkan dengan kontrol negatif. Kurva standar dibuat dengan cara membuat seri konsentrasi hematin (yang telah dilarutkan dalam $\mathrm{NaOH} 0,2 \mathrm{M}$ ). Seri kadarnya adalah : 250; 125; 62,5; 31,25; 15,6; 7,8; dan 3,9 mM.

Analisis data dihitung menggunakan perhitungan persen penghambatan.

$$
\begin{aligned}
& \text { Persen penghambatan } \\
& \qquad=\frac{A-B}{A} \times 100 \%
\end{aligned}
$$

Dengan A adalah kadar hematin pada kontrol negatif (akuades) dan B adalah kadar hematin setelah pemberian senyawa uji. Aktivitas penghambatan polimerisasi heme dinyatakan dalam $\mathrm{IC}_{50}$ (kadar ekstrak yang mampu menghambat polimerisasi hem hingga 
$50 \%$ ). Nilai $\mathrm{IC}_{50}$ ini diperoleh menggunakan analisis probit. Perbedaan nilai $\mathrm{IC}_{50}$ dihitung menggunakan uji independent sampleT-test.

\section{HASIL DAN PEMBAHASAN}

Nilai persen penghambatan heme (1)N-(2-nitrobenzil)-1,10-fenantrolinium iodida (Tabel I) konsentrasi 5; 2,5; 1,25; 0,63; 0,31 $\mathrm{mg} / \mathrm{ml}$ secara berurutan masing-masing sebesar 47,798; 44,756; 43,146; 47,026; 47,996 \%, persen penghambatan (1)-N-(4nitrobenzil)-1,10-fenantrolinium iodida (Tabel I) pada konsentrasi5; 2,5; 1,25; 0,63; 0,31 $\mathrm{mg} / \mathrm{ml}$ secara berurutan adalah 74,761; 76,598; 54,249; 48,058; 45,210 \% dan persen penghambatan klorokuin (Tabel I) pada konsentrasi $5 ; 2,5 ; 1,25 ; 0,63 ; 0,31 \mathrm{mg} / \mathrm{mL}$ yaitu 25,193; 20,878; 8,731; 5,477; 4,607 \%. Dari hasil tersebut diketahui bahwa semakin besar konsentrasi klorokuin semakin besar pula persentasi penghambatan yang dihasilkan. Rerata nilai IC $_{50}$ klorokuin sebesar 25,498 $\pm 1,876 \mathrm{mg} / \mathrm{mL}$, dan rerata nilai $\mathrm{IC}_{50}$ senyawa baru (1)-N-(4-nitrobenzil)-1,10fenantrolinium iodida $0,571 \pm 0,071 \mathrm{mg} / \mathrm{mL}$ sedangkan nilai IC $_{50}$ (1)-N-(2-nitrobenzil)1,10-fenantrolinium iodida tidak dapat ditentukan.

Senyawa baru turunan (1)-N-benzil 1,10-fenantrolin memiliki substituen gugus nitro $\left(\mathrm{NO}_{2}\right)$ pada gugus benzil. Gugus nitro merupakan suatu gugus yangcukup stabil terhadap hidrolisis ataupun oksidasi (Mc Murry, et al., 2004). Sesuai dengan HKSA pada senyawa benzil akan terjadi penurunan muatan bersih pada atom N1 akan mengakibatkan adanya peningkatkan aktivitas antimalaria, maka senyawa baru ini memiliki aktivitas antimalaria yang lebih tinggi.Penghambatan polimerisasi heme dapat melalui (1) interaksi antara senyawa terpenoid, fenol dan sterol dengan sistem elektronik heme (2) ekstrak tersebut terdiri dari senyawa-senyawa yang memiliki gugus hidroksil yang dapat berikatan dengan ion besi heme (Basilico et al., 1998).

Adanya gugus benzil pada atom N1 mengakibatkan peningkatan aktivitas antimalaria, hal ini terbukti dalam penelitian ini kemampuan penghambatan polimerisasi heme (1)-N-(4-nitrobenzil)-1,10fenantrolinium iodida (Gambar 1) lebih baik dibandingkan klorokuin. Namun, aktivitas penghambatan polimerisasi heme (1)-N-(2nitrobenzil)-1,10- fenantrolinium iodida tidak dapat ditentukan hal ini kemungkinan besar hal ini terkait dengan karakteristik senyawa (1)-N-(2-nitrobenzil)-1,10-fenantrolinium iodida yang mudah menguap sehingga sulit untuk mendapatkan nilai penghambatan polimerisasi heme yang optimal.
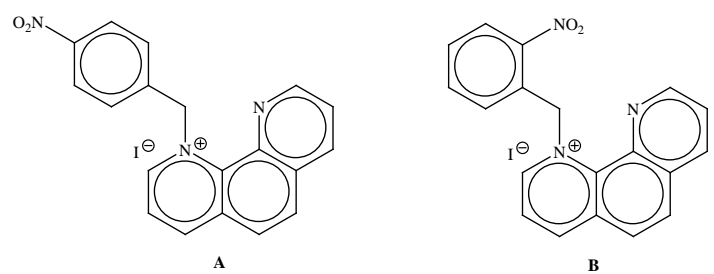

Gambar 1. A; (1)-N-(4-nitrobenzil)-1,10fenantrolinium iodida, B; (1)N-(2-nitrobenzil)-1,10fenantrolinium iodida

Keberadaan gugus nitro pada senyawa turunan fenantrolin terbukti mampu meningkatkan aktivitas penghambatan polimerisasi heme, hal ini didasarkan pada penelitian penghambatan polimerisasi heme terhadap senyawa $\mathrm{N}$-(3,4-dimetoksibenzil)1,10-fenantrolinium bromida dan nilai $\mathrm{IC}_{50}$ yang didapatkan adalah 3,63 mM (1,491 $\mathrm{mg} / \mathrm{mL}$ ) (Fitriastuti D, et al., 2014). Sehingga, terbukti nilai $\mathrm{IC}_{50}$ senyawa (1)-N-(4nitrobenzil)-1,10-fenantrolinium iodida lebih kecil jika dibandingkan dengan nilai $\mathrm{IC}_{50}$ senyawa $\quad \mathrm{N}$-(3,4-dimetoksibenzil)-1,10fenantrolinium bromida $(0,571 \mathrm{mg} / \mathrm{mL}<$ $1,491 \mathrm{mg} / \mathrm{mL}$ ). 
Tabel I. Pengaruh (1)-N-(2-nitrobenzil)-1,10-fenantrolinium iodida dan (1)-N-(4nitrobenzil)-1,10-fenantrolinium iodida terhadap aktivitas penghambatan polimerisasi heme dibandingkan dengan klorokuin

\begin{tabular}{ccccc}
\hline Bahan & $\begin{array}{c}\text { Konsentrasi } \\
\mathbf{( m g / m l )}\end{array}$ & $\begin{array}{c}\text { Rerata kadar beta } \\
\text { hematin } \mathbf{( m M}) \pm \text { SD }\end{array}$ & $\begin{array}{c}\text { Rerata } \\
\text { \%penghambatan } \\
\mathbf{\mathbf { S } D}\end{array}$ & $\begin{array}{c}\text { Rerata nilai IC } \\
\mathbf{( m g} / \mathbf{m L}) \pm \text { SD }\end{array}$ \\
\hline (1)-N-(2- & 5 & $97,381 \pm 5,990$ & $57,798 \pm 2,596$ & \\
nitrobenzil)-1,10- & 2,5 & $127,476 \pm 6,896$ & $44,756 \pm 2,989$ & Tidak dapat \\
fenantrolinium & 1,25 & $131,190 \pm 2,459$ & $43,146 \pm 1,066$ & ditentukan \\
iodida & 0,63 & $122,238 \pm 0,786$ & $47,026 \pm 0,341$ & \\
& 0,31 & $120,000 \pm 1,030$ & $47,996 \pm 0,446$ & \\
(1)-N-(4- & 5 & $58,238 \pm 0,733$ & $74,761 \pm 0,318$ & \\
nitrobenzil)-1,10- & 2,5 & $54,000 \pm 0,378$ & $76,598 \pm 0,164$ & \\
fenantrolinium & 1,25 & $105,571 \pm 8,918$ & $54,249 \pm 3,865$ & $0,571 \pm 0,071$ \\
iodida & 0,63 & $119,857 \pm 7,692$ & $48,058 \pm 3,333$ & \\
& 0,31 & $126,429 \pm 0,247$ & $45,210 \pm 0,107$ & \\
& 5 & $97,979 \pm 0,916$ & $25,193 \pm 0,699$ & \\
Klorokuin & 2,5 & $103,633 \pm 0,380$ & $20,878 \pm 0,290$ & $25,498 \pm 1,876$ \\
& 1,25 & $119,540 \pm 0,773$ & $8,731 \pm 0,591$ & \\
Aquades & 0,63 & $123,802 \pm 0,637$ & $5,477 \pm 0,486$ & \\
& 0,31 & $124,941 \pm 0,898$ & $5,219 \pm 0,686$ & - \\
DMSO & & 230,750 & & - \\
\hline
\end{tabular}

Senyawa (1)-N-(4-nitrobenzil)-1,10fenantrolinium iodida memiliki nilai $\mathrm{IC}_{50}$ lebih kecil daripada klorokuin. Uji independent sampel T-test dilakukan untuk mengetahui apakah ada perbedaan bermakna antara nilai $\mathrm{IC}_{50}$ klorokuin dengan ekstrak etanol batang brotowali. Uji independent sampel T-test digunakan untuk menguji kesamaan rata-rata dari 2 populasi yang bersifat independent, dimana peneliti tidak memiliki informasi mengenai ragam populasi (Utami, 2005). Hasil analisis menunjukkan bahwa IC $_{50}$ klorokuin dengan $\mathrm{IC}_{50}$ senyawa baru (1)-N-(4-nitrobenzil)-1,10fenantrolinium iodida memiliki nilai yang berbeda dan bermakna (signifikansi $0,000 \leq$ $0,05)$.

\section{KESIMPULAN}

Kemampuan penghambatan polimerisasi heme (1)-N-(4-nitrobenzil)-1,10fenantrolinium iodida lebih baik dibandingkan dengan klorokuin ( $\mathrm{IC}_{50}$ (1)-N-(4-nitrobenzil)1,10-fenantrolinium iodida $0,571 \pm 0,0712$
$<\mathrm{IC}_{50} \quad$ klorokuin $\quad 25,498 \pm 1,876 \quad \mathrm{mg} / \mathrm{mL}$ ) sedangkan senyawa (1)-N-(2-nitrobenzil)1,10-fenantrolinium iodida tidak memiliki aktivitas penghambatan polimerisasi heme.

\section{UCAPAN TERIMAKASIH}

Terimakasih disampaikan kepada DIKTI atas program Hibah Pekerti Tahun Anggaran 2013/2014.

\section{DAFTAR PUSTAKA}

Cowman AF, D Galatis, and JK Thompson, 1994, Selection for Mefloquine Resistance in Plasmodiumfalciparum is linked to Amplification of the PFMDR1 Gene and Cross-Resistance to Halofantrine and Quinine, USA: Proceedings of the National Academy of Sciences,91: 1143-1147.

Fitriastuti, D., Mardjan MID., Jumina, Mustofa, 2014, Synthesis and HemePolymerization Inhibitory Activity (HPIA) Assay OfAntiplasmodium of (1)-n-(3,4- 
dimethoxybenzyl)-1,10-

Phenanthrolinium Bromide From

Vanillin, Indonesian Journal of Chemistry, 14 (1), 1-6.

Guetzoyan, L., Yu, X., Ramiandrasoa, F., Pethe, S., Rogier, C., Pradines, B., Cresteil, T., Perree-Fauvet, M., dan Mahy, J., 2009, Antimalarial acridines: Synthesis in vitro activity against $P$. falciparum and interaction with hematin, Bioorganic \& Medicinal Chemistry, 17, 8032-8039.

Hadanu, R., Mastjeh, S., Jumina, Mustofa, Sholikhah, E.N., Wijayanti, M.A., and Tahir, I., 2007, QuantitaveStructureActivity Relationship Analysis (QSAR) Of Antimalarial 1,10-Phenanthroline Derivatives Compounds, Indonesian Journal of Chemistry, 7, 1, 72-77.

Kublin JG, JF Cortese, EM Njunju, RA Mukadama, JJ Wirima, PN Kazembe, AA. Djimde, B Kouriba, and CV Plowe. Reemergence of ChloroquineSensitive Plasmodium falciparum Malaria after Cessation of Chloroquine Use in Malawi, The Journal of Infectious Diseases, 2003; 187: 18701875.
Utami, Herni, 2005, Modul Praktikum Analisis Variansi Terapan, Laboratorium Komputasi Statistika dan Matematika Program Studi Statistika, Universitas Gadjah Mada, Yogyakarta

Widjayanti, M.A., Solikhah, E.N., Tahir, I., Hadanu, R., Jumina, Supargiono, and Mustofa, 2006,Antiplasmodial Activity and Acute Toxicity of $\mathrm{N}$-alkyl and Nbenzyl-1, 10-Phenantroline Derivatives in Mouse Malaria Model, Journal of Health Science, 52, 6, 794799.

Winstanley P, Ward S, Snow R, \& Breckenridge A, 2004, Therapy of Falciparum Malaria in Sub-Saharan Africa: from Molecule to Policy,American society for microbiology journals, 17(3): 612-637.

Yapi, A.D., Mustofa, M., Valentin, A., Chavignon.O., Teulade., J., Mallie, M., Chapat, J., and Blace,Y., 2000,New Potential Antimalarial Agents: Synthesis and Biological Activities of Original Diaza-analogs of Phenanthrene,Journal chemical \& pharmaceutical bulletin., 48, 12, 18861889. 